\title{
Aristotle and the Omọlúwàbí Ethos: Ethical Implications for Public Morality in Nigeria
}

\author{
Sunday Olaoluwa Dada \\ Department of Philosophy \\ Ekiti State University, Nigeria \\ sunday.dada@eksu.edu.ng
}

\begin{abstract}
This essay explores the philosophical affinity between Aristotle's concept of virtue as character habituation and the Yorùbá ethical and ontological understanding of omolúwàbí as the foundation for re-examining the philosophical foundation of democratic governance in Nigeria. Based on the Aristotelian insistence that the good life is the end of politics, the essay argues for a rethinking of the concept of public morality as character-based political dynamics that enables politicians to think more about the social contract between the government and the governed, rather than an amoral understanding of politics that eschew morality and undermines the well-being of the citizens. The absence of public morality, the essay argues, has resulted in a neopatrimonial framework within which the political elite willfully circumvent constitutional rules and regulation in order to vitiate the public interest. The essay concludes by arguing for a rigorous public enlightenment as well as a reform of the educational curriculum through an injection of virtue ethics.
\end{abstract}

Keywords: Omolúwàbí, Aristotle, Character, Virtue, Public morality 


\section{Introduction}

One of the areas of interest in politics today is the consideration of the ethical behavior of public officials and the moral contents of public policy; and most public criticism has focused on the former. The reason for this is that we live in a time, especially in Nigeria, when we often find ourselves disappointed by the moral character of leaders as well as the disappointing display of immorality in official matters. Elected political leaders and politically appointed officials are expected to have some moral commitments both at the private and public levels. When a person is elected into political office, one of the conditions for electoral trust is the person's moral track record, especially with regard to integrity. Integrity in this sense ties in with the transparent handling of matters of governance in ways that will eventually benefit those the public officers are representing.

The significance of public morality lies in its ensuring that a leader's moral dynamics are sufficiently firm and commendable as to be suitable for the critical task of holding public office. The idea of public morality intersects that of democratic governance at the point of making sure that strong institutions are not willfully undermined by degenerate politicians and other public office holders. Democratic governance is founded on strong institutions that are put in place to facilitate the mutually empowering relationship between government and the governed. Political power, if not properly circumscribed, undermines the public good through the political maneuvers of greedy and unscrupulous public officials and politicians. It is at this point that public policies become side-tracked in a way that benefits the representatives rather than, and even at the expense of, the represented. One of the fears that people have about leaders is that "they will abuse power or that they will distort their sense of self, moral purpose, and accountability" (Ciulla 2003, 54). The temptations posed by the allure of political power therefore become a cogent challenge that must be short-circuited by political leaders if the citizens are to benefit from democratic governance under the watch of conscientious leaders.

How then can democratic governance be enabled through the moral dynamics of good leadership? What is the role of cultural knowledge in facilitating good governance? How, for instance, can a Yorùbá moral philosophy enable the conscious rehabilitation of the idea of public morality in Nigeria? These questions form the bedrock of this essay. In the first section, I will be concerned with a critical interrogation of democracy in Nigeria and the absence of public morality which has resulted in a neo-patrimonial framework within which the political elite willfully circumvent constitutional rules and regulation in order to vitiate the public interest. We argue here that public morality is one of the values that undergird democracy anywhere in the 
world, and that this value contributes an ethically worthwhile component to the social contract between the government and the governed. The second section examines the Yorùbá concept of omọlúwàbí through an interrogation of Aristotle's understanding of the relationship between virtue and character. The third and final section outlines the possible ways by which the omolúwàbi ethos could serve as an ethical platform for reinventing the anomic Nigerian polity. It also considers the policy implications of the omolúwàbi ethos in rethinking our institutional deficiency in Nigeria.

\section{Democracy and Public Morality in Nigeria}

Democracy is simply government established through the consent of the people. And this form of government has become the accepted governance norm across the globe. One of the fundamental reasons for this is that the ideals that democracy embraces are those which foster equality, justice, and fairness. According to Diamond et al., democracy can be described as a political system that meets the three essential conditions of

meaningful and extensive competition among individuals and organized groups (especially political parties) for all effective positions of governmental power, at regular intervals and excluding the use of force; a 'highly inclusive' level of political participation in the selections of leaders and policies, at least through regular and fair elections, such that no major (adult) social group is excluded; and a level of civil and political liberties-freedom of expression, freedom of the press, freedom to form and join organizations-sufficient to ensure the integrity of political competition and participation (1990, 6-7).

From this perspective, democracy is essentially a system that enhances and reinforces popular participation and fundamental human rights. In agreement with this, Franceschet sees democracy as involving three basic requirements: non-violence, political participation and control, and political equality (Franceschet 2009, 21-28).

The commencement of the democratic dispensation in Nigeria, since 1999, therefore calls for some sense of optimism toward the transformation of the Nigerian polity into an empowering one for the Nigerian citizens. This is because democracy, at least in principle, assures that the social contract-which ensures that the aspirations of citizens will be the top priority of the government-will be honored. The dawn of a new democratic era in Nigeria raises the hopes that Nigerians might finally start enjoying the dividends of inclusive 
political participation and representative policymaking that will jumpstart infrastructural development.

Nigeria's democratic manifestation is first denoted by the regularity of elections since 1999. The fact that Nigeria has entered into the democratic era is attested to by the many elements of institutional democracy which are now in place in the country. In a democracy, the authority to govern is derived or acquired from the people that are governed. This is achieved through regular elections where citizens elect their representatives. Elections involve a set of activities leading to the (s)election of one or more persons out of many to serve in positions of authority in the society. What gives credibility to the process and legitimacy to the elected persons is that the election is conducted according to all constitutional and legal dictates, and hence adjudged free and fair even by the contestants. According to Huntington (1996), a political system is democratic if its most powerful collective decision makers are chosen through fair, honest and periodic elections in which candidates freely compete for votes and in which virtually the entire adult population is eligible to vote. For elections to be credible, it must be competitive; that is, the candidates involved must be given equal opportunity. This implies that there must be no attempt to marginalize any candidate. According to Wojtasik, "competition ensures legitimacy of decisions taken by the elected representatives, provided all adults are eligible to participate in the elections" $(2013,27-28)$.

The Independent National Electoral Commission (INEC), between 1999 and 2015, has conducted five consecutive general elections, and is preparing for another in 2019. This can be considered a drive towards the consolidation of democratic governance in the country. This should not however blind us to the fact that the electoral process in Nigeria is fraught with many problems that threaten the democratic institutions themselves. It is no wonder that the same process that strengthens an institution when implemented properly also undermines it when attention is not paid to its dynamics. Nigeria is still battling with the electoral process. For instance, the 2007 election, which voters hoped would be free and fair, was reported in the newspapers to be fraught with fraud and violence (Vasudevan 2007, 2499). The media was filled with reports of stuffed boxes, voter intimidation, and phony results. Vasudevan catalogued reports of the election:

Nigeria's independent observers' group-the Transitional Monitoring Group (TMG) - called the elections a "sham". The observers of the European Union observed that the elections could hardly be called "credible by basic international standards" and had "failed to meet the hopes and expectations of the Nigerian people". Madeleine Albright, former US secretary of state, indicated that "the election process failed the Nigerian 
people". The Inter- national Republican Institute, a US based non-governmental organisation argued that the elections in Nigeria were the worst that they had monitored, with standards below what they had seen even in backward, poverty-ridden Somalia. Wole Soyinka, Nigeria's Nobel Prize winner, called it "the most insulting elections in this country" and called for their cancellation given the massive irregularities. The Financial Standard, a newspaper of Nigeria, pointed out that nearly 70 per cent of the presidential ballot papers printed in South Africa were consciously and in connivance with the Independent National Electoral Commission (INEC) hoarded in a warehouse in Johannesburg so as to deliberately create an artificial scarcity. The newspaper maintained that the INEC was a handmaiden of the PDP - the party in power and also wondered whether South Africa was an accidental accomplice The Africa Report concluded that INEC itself was neither "in- dependent" nor "credible". The Human Rights Watch Group was more on target when it simply said that "Nigeria has not held a free and fair general election since the end of military rule" (2007, 2499).

The above outlines what has been a constant manifestation in Nigeria's elections since the First Republic, and the first election in 1962. There is no doubting the fact that the coup that ousted the First Republic was justified against the backdrop of the massive rigging that undermined the credibility of the elections in the Western region in 1965. As Akinola (2013) relates, the attempt by the leadership of Nigerian National Democratic Party (NNDP) to impose itself on the people of the Western region led to the violence which culminated in the killing of NNDP supporters and the burning of houses. This is not to say that the rigged election was the only reason for the military intervention. There are other reasons such as the heterogeneity of the country and the politics of regionalism in the immediate post-independent era which polarized the country. However, elections become significant because they were also critical in the collapse of the Second Republic led by Shehu Shagari. The violence that erupted in August 1983 in Ondo State is a case in point. According to Apter (1992), the violence was caused by the popular reaction against the rigged gubernatorial election in favor of National Party of Nigeria (NPN) in a state that was overwhelmingly Unity Party of Nigeria (UPN). The fact that electoral fraud such as ballot snatching and violence have accompanied Nigeria's elections shows that the underlying cause of the failure of the first and second republics have not been properly understood and tackled.

One important dimension of how critical Nigeria's political institutions have become derives from the perception of these institutions, which leads to anti-democratic consequences. Politics becomes essentially zero-sum because 
public offices have imbibed the logic of prebendalism and patrimonialism, the two unfortunate facts of political life in Nigeria, that ensured that public office holders violate the imperatives of the social contract between the governed and the government. Thus, skewed dynamics of public morality become a critical factor in the sustenance of Nigeria's democratic dispensation.

\section{What is Public Morality? The Nigerian Example}

In A Moral Vision for America, Bernadin says that an issue is one of public morality when it relates to or affects the public order of society. Public order, for him, encompasses three goods, namely, "public peace, essential protection of human rights and commonly accepted standards of moral behavior in a community" (Bernadin 1998, 46). Among these three components, the one that should be taken as primarily defining public morality is the "commonly accepted standard of moral behavior in a community". The reason is that its formulation and acceptance would yield the other two elements. Weinstew defines public morality as the set of standards prescribing right conduct within social-cultural organization. According to him, "It is the morality exemplified by the system of social roles that makes up social-cultural organization. Thus, in so far as one can define systems of social roles, public morality is present as the standards prescribed by these roles" $(1973,10)$. It is a truism that standards prescribing the right conduct within sociocultural environment have been and continue to be an integral aspect of the human condition in its social and cultural phases. They have also been an inseparable component of social harmony. Public morality essentially involves imposing a form of moral behavior on politicians and public office holders in order to ensure that their personal moral codes do not undermine the public interest. In this sense, therefore, we can adduce the argument that any move away from public morality in national politics entails a weakening of Nigeria's democracy.

Humans are always in a state of becoming. The reason is that the structure of human existence itself is dialectical. According to Weinstew,

In the process of activity, people are continuously moving beyond themselves and losing themselves in their world. This is the dialectical moment of self-transcendence. However, through self-transcendence human beings incorporate parts of the world into themselves and thereby find themselves more fully than they could have before action was initiated $(1973,10)$.

The import of this is that in the process of engaging in the existential business of living and in public affairs, there is the tendency to find ourselves doing what we do not intend. This is where the significance of public morality 
surfaces. If there are no moral standards that act as a check, the good person can be transformed (un)wittingly into a bad person in the political arena. Leaders are not in power to accumulate money, amass power and gain influence. They are there as symbols of what is right and what values the society should uphold. The function of public morality is to delineate what is right and what is acceptable in the political terrain. And it is significant because it will circumscribe both the personal and the political actions of political leaders.

According to Jansen, public morality, in addition to the law, forms the normative foundation of every society. Public morality, according to him, "constitutes the mutually justified demands of in individuals and thus stabilizes individual expectations of conduct... [and] serves as the measure of normative correctness in both law and politics" $(1998,1)$. Unless political action and judicial processes follow some acceptable moral convictions and standards, they cannot lay claim to legitimacy and binding force. The society must know what is morally valid so that substance can be given to its moral norms. Once substance is given to the moral norms, it becomes valid and morally binding. Public morality must be adhered to even when particular contents and norms are against some individuals' moral convictions. Of course, as Jansen remarks, it is normally not easy to accept moral norms in public when they conflict with one's own views $(1998,6)$. However, moral consensus is possible when each person looks at the moral norms on their own merits.

What counts as public morality is what Jansen refers to a freestanding morality. It is freestanding in the sense that though valid for all, it is not justified on the basis of one single ideology or worldview adhered to by a few participants. To idealize or objectify a moral norm that does not achieve consensus on the ideological level would be unacceptable to those who reasonably do not share such convictions. For this reason, Jansen contends that a freestanding conception "must be justifiable independently of a single ideological conception of moral". He is however of the opinion that such moral consensus is possible:

It is therefore not Utopian to say that consensus on freestanding norms of public morality is at least possible. All in all, it is firstly important to note that a freestanding conception is the result of moral agreements and not of common epistemic insights. It forms an additional normative level of common morality alongside individual moral convictions (Jansen 1998, 1).

The justification for public morality is that there is, according to Wellborn, "an empirical reality in any given society which can be designated as a common morality" (1978, 493), which consists of the most widely shared moral 
convictions of the society. Public morality is then "that part of the common morality which is translated by the society into statutory law" (Wellbourn 1978, 493).

There is another twist to the meaning of public morality as suggested in the definition given by Dwight Waldo. According to him, public morality relates to "action directed to the interests and welfare of more inclusive 'populations' than self, family, clan or tribe" (Waldo 1974-1975, 44). That is to say, apart from looking at public morality from the point of view of acceptable common standard of behavior within a sociopolitical environment, it also has to do with how public officials use public goods and public resources. When a leader or public official uses his or her office to benefit personal interest or family in accordance with neo-patrimonial logic, then such an official has violated the tenets of public morality, and hence has acted immorally. This constitutes a conflict of interest issue. Conflict of interest arises, according to Williams, in a situation in which an employee has a private financial interest sufficient to influence, or appear to influence, the exercise of his or her public duties and responsibility $(1985,6)$. Another way of saying this is that a conflict of interest exists when a public employee's public responsibilities clash, or appear to clash, with his or her private economic affairs. According to Mafunisa, "in its narrowest and perhaps crudest sense, conflict of interest refers to a set of circumstances in which a public employee uses his or her government position, either overtly or covertly, in such a way as to achieve personal monetary gain. In its broadest sense, it refers to any situation in which an employee's public responsibility and private interests conflict and does not suggest that the clash has been resolved to the advantage of the private rather than the government interest" $(2003,5)$. According to Willbern,

The general presumption is that the moral duty of an official or employee of a unit of government is to pursue the "public interest" i.e., the needs and welfare of the general body of citizens of the unit. His own interests, and the interests of partial publics of which he may be a member, are to be subordinated if they differ from the broader, more general, public interest-as they almost inevitably will, from time to time $(1984,104)$.

The public office holder is responsible to the generality of the people, and not to himself and his ethnic or religious affiliations. In a situation where there is conflict of interest, he or she ought to prioritize the interest of the citizenry. What we see in the Nigerian situation is an aberration of these moral and political norms. Public office holders prioritize themselves and their personal interests as primary. This is the cause of the numerous scandals involving embezzlement of public funds, bribery, contract distortions, budget 
padding, etc. This is a great concern because it is not only immoral to use one's official position to benefit oneself at the expense of the public that one intends to serve in the first instance, but also because it reduces public trust and confidence in the integrity and impartiality of public functionaries. All dimensions of the conflict of interest issue, from "godfatherism" and favoritism to nepotism and ethnic biases crucially undermine democratic probity.

What is the relationship between public morality and conformity to the law? Willbern argues that public officials are morally bound to tell the truth, keep promises, respect the person and properties of others, and to abide by the demands of the law, like any other citizen. This is very important because the public official is first of all a person and an individual member of society. In Nigeria, public morality has broken down in this area. It seems like those in official positions are above the law. The Nigerian Code of Conduct Bureau (CCB) constitutes the statutory organ that is responsible for monitoring the conduct of public officials. Its mandate is "To establish and maintain a high standard of morality in the conduct of government business and to ensure that the actions and behavior of public officers conform to the highest standards of public morality and accountability" The establishment and functions of the CCB feature prominently in the Nigerian Constitution. The Fifth Schedule of the Constitution states clearly what is expected from all public officers of the Federal Republic of Nigeria. For instance, paragraph one states: "A public officer shall not put himself in a position where his personal interest conflicts with his duties and responsibilities." Paragraph 11(b) further states that a public officer must "at the end of his term of office, submit to the Code of Conduct Bureau a written declaration of all his properties, assets, and liabilities and those of his unmarried children under the age of eighteen years."

However, there is a very wide gulf between the law and its enforcement. The essential problem with public morality derives from the absence of a constitutional order that ensures that laws are upheld, and that no one can violate the rules and protocols of public office with impunity. But this is what happens, and has become the order of the day. Even though the CCB has the power to "ensure compliance with and, where appropriate, enforce the provisions of the Code of Conduct of any law relating thereto," it has become effete in its capacity to police public morality in Nigeria. And unfortunately, this ineffectiveness is a large part of the anti-corruption institutions in the country. The ongoing case against the president of the Nigerian Senate, Olusola Saraki, is the highest profile case pursued by the CCB since the commencement of the democratic dispensation in 1999. No Nigerian, I am sure, have any illusion as to how the case will turn out.

1 http://www.ccb.gov.ng/ 
The spate of stealing public money among politicians in office has become so alarming. In fact, for public office holders, stealing and embezzlement have become normal practice to the extent that it is always said that "government does not abhor stealing; it is only the thief who is careless enough to be caught that the law descends heavily upon" (Falola and Adebayo 2000, 256). Apart from the enormity of the loots of past Nigerian leaders that the federal government of Nigeria has recovered so far, the public sphere is daily filled with the news of billions of naira that public officials steal or embezzle. It takes litthe reflection to see how the selfish perception of political offices could easily lead not only to prebendal politics, but also the violence attached to winning elections for public offices, or the spate of political assassinations. Assassination has become an instrument of settling a score or for dealing with one's political opponents. Durotoye provides a list of politically motivated killings in Nigerian between 1999 and 2000, with such high profile killings like that of Bola Ige, a former Nigerian justice minister and attorney general (killed on December 23, 2001); Marshall Harry, the national vice chairman for the South-South Zone of the now defunct All Nigeria's People's Party (killed in December, 2001); Ogbonnaya Uche, an ANPP senatorial candidate in the southeastern state of Imo and former commissioner in the Imo State government (shot in his home in Owerri on February 8, 2003, he died two days later); and so on (2014, 235-242). The most troubling part of these killings is that most of them have not been solved, and the perpetrators have not been brought to justice (Durotoye 2014, 235-242). While Igbafe and Offiong think that the reason for this is "the ineffectiveness and inefficiency of the national security outfit, particularly the police that has failed to live up to its duties by apprehending the culprits and their collaborators" (Igbafe and Offiong 2007, 12), I suspect that a more fundamental reason must be sought in the very nature of politics in Nigeria, and the complicity of those in political offices in the protection of their spoils of office.

In the next section, I will interrogate the Yorùbá idea of omolúwàbí as a possible discursive mediation of public morality in Nigeria. My methodological approach will be to examine the concept of omọlúwàbí using Aristotle's virtue ethics. This is because in Aristotle, we find the moderation of the individual in a way that is similar to the Yorùbá moral imperative of individual character. Omọlúwàbí has significant implications for Nigerian democracy, and the starting point is to accept the Aristotelian hitching of ethics to politics. 


\section{Aristotle on Virtue and the Yorùbá Ọmolúwàbí Ethos}

In Aristotle, we find an inseparable relationship between morality and politics. Outlining what such a relationship entails was his sole concern in the Nicomachean Ethics. Aristotle conceives ethics and politics as practical sciences that deal with human beings as moral agents. Ethics is concerned with individual moral action while politics is concerned with human actions in the political community. This shows that the task of politics is much more than the acquisition of political power or even the provision of what is necessary for the life of the community. The well-being of the community is not confined to economic security and internal and external peace. On the contrary, the primary task of politics is to care for the citizens' acquisition of knowledge and their moral conditioning. Politics then becomes an application at a larger scale of what ethics tries to do at the individual level-institute and teach action that will bring happiness. In order accomplish this, politics "lays down laws about what we should do and refrain from" (Aristotle 2004, 4). What this suggests is that both ethics and politics are oriented towards action, and the right action. For Aristotle, the end of politics is the best of ends and the main concern for politics is to engender a certain character in the citizens and to make them good and disposed to perform noble actions (Aristotle 2004, 16). The concept that links ethics and politics in Aristotle is telos, that is, ends. Aristotle considers everything as having ends, and the end that humans pursue is happiness (eudemonia). To be able to achieve this, Aristotle thinks that man has to live a life of virtue. In other words, a person who is not living a virtuous or moral life will likely not be able to achieve happiness. But then, even Aristotle understands that it is not easy to live a virtuous life. To become virtuous, human beings need to live under the right conditions. The right condition is a well-ordered and well-constructed political community.

Aristotle's discussion on virtue bothers on how to behave well in order to achieve the good life. He defines (moral) virtue as a disposition to behave in the right manner and as a means between the extremes of excess and deficiency. Virtue for Aristotle is character. And character is not a natural capacity with which one is endowed; it is not something we have and then begin to display, like the capacity to see. On the contrary, it is an acquired tendency, like acquiring a skill. And just as we become perfect in the continuous reproduction of what we learn to produce, becoming virtuous comes by virtuous habituation; that is, by doing what is good (Aristotle 2004, 23-24). A state of character arises from the repetition of similar good habits. Hence, you cannot say that someone is virtuous or has good character if he or she does not do what is good and right. 
Aristotle also emphasizes that moral virtue is not only gauged by the final action, the same way the final product defines a craft. Virtue is not just defined only by doing what is right, but is also determined by the state of mind from which the action springs. A virtuous act is that which is done intentionally, chosen deliberately for its own sake, and arises from a fixed disposition that has been developed through habituation. Character then becomes a deliberately cultivated disposition. What this shows, according to Tessitore, is that:

While it is neither necessary nor possible to possess virtue in order to become virtuous, one can and must cultivate the external actions appropriate to virtue as a part of the process of becoming genuinely virtuous. Aristotle's earlier emphasis on the centrality of correct opinion and proper education becomes, with this explanation, more fully intelligible. These exert a powerful influence on the type of actions that become habitual and, as such, provide the indispensable ground for the development of full virtue. $(1996,26)$.

According to Aristotle, "it is not unimportant, then to acquire one sort of habit or another, right from our youth; rather, it is very important, indeed all-important" (Aristotle in Steinberger, 2000, 367). ${ }^{2}$ Aristotle could be saying two things here. The first is that a lengthy process is required for a person to get the appetitive part of his soul in line with the rational part, a conjunction which is require for virtuous living. The second is that it is important to have a long history of moral character, as this is critical to how people look at us as individuals. The reason is that people do not have short memories as to the history of human behavior. Rather, such history constitutes what people use as a basis for assessing us morally. For instance, when we want to select a leader for a political office, it is seems only logical to look at the person's track record in moral terms and assume that if the person has done well in the past, he or she would most likely do well in the future. An example can be found in American history when the American public subjected presidential candidate Gary Hart to scorn for cheating on his wife and was consequently forced out of the presidential race (Ciulla 2003). The current president of the US, Donald Trump, is facing a similar opprobrium at the moment over shady dealings. However, the important question is whether Aristotle forecloses moral reorientation as one grows more mature in society. That someone has been morally

2 This quotation of Aristotle from Stienberger's (2000) suits my purpose better than the rendering in Crisp (2004). 
bankrupt in the past does not foreclose the possibility of reclaiming himself in the future. Habituation is a process that can be picked up at any time.

For Aristotle, the focus of virtue, character, and consequently morality, is how to act in the right way, for that is how we can benefit from moral examination. The purpose of ethics is not just for intellectual contemplation. He writes:

The branch of philosophy we are dealing with at present is not purely theoretical like the others, because it is not in order to acquire knowledge that we are considering what virtue is, but to become good people otherwise there would be no point in it. So we must consider the matter of our actions, and in particular how they should be performed, since, as we have said, they are responsible for our states developing in one way or another (Aristotle 2004, 24 ).

In other words, knowing what virtue is is not as important as knowing how to act (that is, do what is good/right). The all-important purpose of this is that what we do is what determines the character of the state we control. In other word, what we turn out to be in terms of our character is a function the actions we are habituated towards. A person cannot become brave by refraining from actions that demonstrate bravery. Someone who is coming to the position of leadership for the first time must have proven himself at the private level to earn the quality that will make people believe that $\mathrm{s} / \mathrm{he}$ is capable of standing in that office without moral failure. Actions are very important, but as Aristotle points out, an action that becomes excessive is bad. The right sort of character habituation is that which avoids excess and deficiency, and maintains a mean position. For him,

The same goes, then, for temperance, courage and the other virtues: the person who avoids and fears everything, never standing his ground, becomes cowardly, while he who fears nothing, but confronts every danger, becomes rash. In the same way, the person who enjoys every pleasure and never restrains himself becomes intemperate, while he who avoids all pleasure, as boors do, becomes, as it were, insensible. Temperance and courage, then, are ruined by excess and deficiency, and preserved by the mean (Aristotle 2004, 24).

An important question, an answer Aristotle elucidates in the Nicomachean Ethics, is how the process of character habituation is to be effected. For him, it is through law and education. These are needed because most people would like to follow their natural passion. So, Aristotle gives no room to moral luck. 
People do not turn out virtuous unless they so deliberately cultivate virtue, and that is why training from an early age becomes significant.

Aristotle clearly envisages that the habituation necessary for the development of moral virtue can best be effected by law. The purpose of law in the polity is to make citizens good and capable of noble actions. Accordingly, legislators make laws that can habituate the citizens towards good habits. It is the correct way of doing that which, for Aristotle, distinguishes a good political system from a bad one. However, some questions have arisen of the possibility of law producing virtues such as bravery, love, generosity and so on. There is also the question of whether everything prescribed by the law is virtuous. Aristotle does not seem to indicate we can answer this question in the affirmative. We all know that there is the possibility of bad laws. So, if Aristotle is prescribing law as one of the bases of character habituation, then he must be talking about a good law. Aristotle sees law as a means of ensuring proper conduct of the citizens (Aristotle, 2004, 4). Laws are both incentives to right action and power that imposes discipline. He underscores the importance of law when he remarks that:

But if one has not been reared under the right laws it is difficult to obtain from one's earliest years the correct upbringing for virtue, because the masses, especially the young, do not find it pleasant to live temperately and with endurance. For this reason, their upbringing and pursuits should be regulated by laws, because they will not find them painful once they have become accustomed to them. Perhaps it is not enough, however, that when they are young they get the right upbringing and care; rather, because they must continue to practise and develop their habits when they are grown up, we shall need laws for this as well, and generally for the whole of life. For the masses heed necessity rather than argument, punishments rather than what is noble (Aristotle 2004, 200-201).

Along this line, Aristotle takes particular interest in those who are to be lawgivers (legislators). They should be given proper education. This establishes more the relationship between ethics and politics and, not only that, it also indicates that the right moral education is not just a private but more importantly, a public concern (Aristotle 2004).

The other process of character habituation is through proper upbringing in the family. Here, character habituation will be guided, for example, by one's parents or teachers, the primary agents of socialization that are significant for a child's social and moral maturation. The purpose of this process is to develop in the individual practical wisdom, which makes the virtuous person able to get it right in each sphere without guidance from others. Right 
education involves being habituated in pleasure and pain since if these are badly ingrained, virtue is impossible. The significance of education derives from the insistence that universal rules on which laws are based require personal experience to adapt them to particular circumstance. This then implies that a city may have a well-structured legal system, and yet such a city may not be able to produce virtuous people because a proper education is missing. The advantage of family education over law is that it allows virtue to be ingrained in the individual reaching down to all of the individual's internal motivations and impulses. This is contrasted to the understanding of virtue as a mechanical capacity to repeat certain kinds of action. However, as Aristotle himself notes,

The command of a father has no strength or compulsive power, nor in general does that of a single person, unless he is a king or something like that; but law does have compulsive power, and it is reason proceeding from a kind of practical wisdom and from intellect. And people hate a human being who stands in opposition to their impulses, even if he is right to do so; but there is no oppressiveness in the law's prescribing what is good (Aristotle 2004, 201).

What this implies is that parental upbringing and habituation within the family cannot produce the kind of power that the law has over the individual that is being cultivated. However, we should not forget that the family happens to be the first contact of the individual with character habituation and the development of virtue. To my mind, emphasis should be placed on education for character development at the family level. Aristotle seems to suggest this when he points out that individual and private education is preferable to common education:

...education on an individual basis is superior to education in common, as in the case of medical care. For though in general rest and abstinence from food are beneficial for a person in a fever, presumably they may not be for a particular person; and a boxer, presumably, will not prescribe the same style of fighting for all his pupils. It would seem, then, that particular cases are treated with greater subtlety if there is attention to individuals, since each person is more likely to obtain what suits him (Aristotle, 2004, 202).

What he is saying is that private education is more favorable on the ground that it is more adaptable to the individual's special needs.

In any society, there is a way of celebrating the man of character especially when he is involved in the political sphere. This is epideictic rhetoric, which 
Aristotle set out in Rhetoric, composed to deal with the practical necessities and uncertainties of governance in a free society. It posed an alternative to the reign of force imposed by a tyrant and the rule of authority imposed by those deemed superior in moral and intellectual virtue. Rhetoric makes most sense in a world where peers govern themselves. As Aristotle sees the matter, rhetoric applies to free humans who desired neither to experience any form of subjugation nor to impose subjugation upon their fellow citizens. Rhetoric can therefore be firmly situated within an ethical context. As Hauser notes, Aristotle, in response to the uncertain civic conditions of the day, proposes that "a rhetorical practice of adhering to artistic precepts would improve the quality of public life" $(1999,9)$. The role of epideictic rhetoric is to either praise or condemn political figures in the society in order to thereby educate both the politicians and the people on the acceptable political behavior in the society. Rhetoric thus serves as a way of promoting public morality. Rhetors, practitioners of rhetoric, must therefore have rhetorical competence in order to render competent judgment. The rhetors are supposed to be grounded in the moral requirements of their communities since the "prevailing rhetoric is a statement of communal beliefs and commitment as well as a demonstration of the rhetor's practical wisdom" (ibid, 14).

The Yorùbá concept of omolúwàbí is a correlate of Aristotle's person of character. The thesis of this essay is that the omolúwàbi ethos can be mined for an understanding of the character dynamics that is necessary for democracy to flourish through its public office holders in Nigeria. In Yorùbá culture, omolúwàbi is not the name of any specific person, but rather a concept that possesses both normative and descriptive content. As a description, omọlúwàbí denotes an individual who has acquired a moral status that could qualify him as being virtuous. As Aristotle has noted, character is the result of being habituated in what is good and noble. So also omolúwàbí derives from being habitually moral. It is not an appellation one can unilaterally give to oneself. It is conferred by others in society who recognize a person as a morally upright person. Omọlúwàbí is the "morally upright person who exhibits such virtues as honesty, respect (for himself, elders, and for others in general), decency, benevolence, etc." (Bewaji 2004, 399). In the perspective of Jamiu (2007), omolúwàbí describes someone who thorough-bred and is regarded as worthy of being entrusted with positions of responsibility. As a normative concept, it serves as the standard of acceptable moral behavior; that is, it determines the boundaries of what is moral (iwà rere) and what is not moral (iwà búburú). According to Olunlade (2017), the concept of omọlúwàbí is the bedrock of ethics in Yorùbá cultural society. It is, for her, a significant concept that articulates the good habits people should acquire and the duties they should uphold. In other words, it encompasses all the ethical values expected 
of a person as a worthy member of the society. For Jamiu (2007), it is a concept that encompasses all the good attributes an individual must possess before he could be regarded as a good person and the lack of these qualities mean that the person would be described as a bad person.

In traditional Yorùbá society, character (ìwà) constituted an indispensable part of social existence, peace and order, and formed a part of the qualities that a Yorùbá person must possess before he or she can be reckoned with in the community. Like other traditional societies in the world, the Yorùbá have unwritten codes of conduct which are meant to circumscribe proper attitude and behavior. According to Dauda, "İwà as morality is the unwritten constitution for the everyday running of the public and private affairs of the Yoruba nation" (2017, 483). The Yorùbá would say, for instance, ìwà l'ẹwà ("character is beauty") or ìwà l'ẹṣọ èniyàn ("character beautifies the person"). What this shows is that if you have everything and you lack iwà, you are therefore not adorned and not beautiful to behold. The Omolúàbí is the one who has iwà rere (good character), ìwa pẹlẹ (gentle character), ìwà tútù (mild character). To say iwà l'ewà only implies that character is the essence of beauty. Thus, if you have character, you have by that fact become a beautiful person. But this does not mean that if you have beauty, you have character. İwà l'ẹwà suggests, as Afolayan argues, that "beauty goes beyond the superficial adornment of the human body to something deeper that relates to his or her ontological existence" $(2017,886)$.

The Yorùbá believe that ìwà is considered to be the daughter of sùurú (patience). In other words, it is patience that produces good character. As Gbadegesin explains, sùurú is the source of iwà pẹlẹ and ìà rere. For him, a demonstration of iwà pẹlẹ is seen in being mindful of the individuality of others, treating others gently and being tolerant and accommodating of the peculiarity of the existence of others $(1998,304)$. The political killings that are witnessed in Nigerian democracy show the level at which this moral element of Yorùbá culture has been undermined and ignored.

The virtue of being an omolúwàbí is one of the goals of Yorùbá traditional education; to make the child a worthy member of the society. Thus, for example, a person who does not know how to greet, and in a proper language and tone, is said to lack home training (èkọ́ ilé). Such a person cannot be an omolúwàbí. If the person knows how to greet and respect elders and the individuality of other but tells lies, the person is an òpùró (liar) who cannot be trusted or held accountable. Such a person would still not be an omọlúwàbí. And if he combines truth telling with respect but lacks a strong work ethic and is not diligent, then the person is ole (lazy) and cannot be considered an omolúwàbí. The reason is that iṣé ni òogùn iṣẹe, ẹni tí kò șisẹ, yóò jalè ("working hard is the panacea for poverty; anyone who does not work hard will become 
a thief"). This seems to suggest is that the omolúwàbí is a well-rounded person who is not deficient in any area of conduct. This would then imply the omọlúwàbí is a person who, according to Awoniyi, "combines all virtues" (cited in Akanbi and Jekayinfa 2016, 14-15) and is hence morally perfect. But this is not so. Were it so, it would raise an all-important question of whether such a person can be found within the community of humans. The truth is that no one would qualify as an omolúwàbí, as no one can be so virtuous at to be morally impeccable in all spheres of moral assessment. How should we then conceptualize the omọlúwàbí? The omolúwàbi should be seen as someone who is good and dependable and is above board when it comes to what is acceptable within the society. Adebayo Faleti provides a critical insight in this respect. He asks us to think of the omolúwàbi as being to the Yorùbá "what the word gentleman was to English in those days" (2009, 117). From the The World Book Dictionary, Faleti identifies the three attributes of a gentleman that correlates that of an omolúwàbi: "a man of good family and social position; a man who is honourable and well bred; and a man of fine feelings or instinct shown by his behaviour and consideration for others (ibid, 117).

\section{Operationalizing the Omọlúàbí Ethos}

Operationalizing the omolúwàbi ethos in the Nigerian politics would begin with the recognition of the place of morality in politics. Nigerian politics is zero-sum because it is amoral. The context of realpolitik in Nigeria, as we have seen from the preceding analysis, is one in which the end of juicy political offices and political power justifies the means of public immorality. This absence of a moral standard for public life in Nigeria has bred several dangerous consequences. The most glaring is the endangerment of Nigeria's nascent democracy. Politics is now commonly perceived as a dirty game that only those who have guts and grit to commit atrocities can succeed in. The fundamental problem with Nigerian politics, Anele (2010) contends, "is the dominant attitude of our politicians to politics and public office, and their misunderstanding of what political leadership is about. Considering their propensity for 'naira-and-kobo' or 'ówàmbẹ' politics, it can easily be inferred that they are in politics to get their share of the 'national cake." (2010).

In Nigeria, the separation of politics from morality spells doom, as the political landscape already has already demonstrated. We now have a situation of realpolitik in which people play by different rules or by no rules at all. The consequence of such is confusion. It is this confusion that we have been witnessing in Nigeria since the Fourth Republic began. According to Anele, we had a legislature which "spent approximately $\$ 532$ billion to make 532 laws, making the laws one of the most expensive, if not the most expensive, set of 
legislation in the world" (ibid.). Political office holders including ministers, governors, and state commissioners steal millions of money, which are then used to finance ostentatious lifestyles and buy expensive properties both home and abroad. O'Rourke underscores the importance of morality when he remarks that:

Morality is important to politics. Important is not the same as necessary. You can remove morality from politics like you can remove the head from a chicken and they'll both keep going, politics much longer than the chicken. Politics will continue to run around, flap, and spurt blood forever without its morality. What's important about morality in politics is us. We own the chicken farm. We must give our bird-brained, feather-headed politicians morals. Politicians love to think of themselves as "free-range" but they do not have the capacity to hunt or gather morals in the wild. If we fail to supply them with morality, politicians begin to act very scary in the barnyard (2010, 79-80).

In Nigeria, we have to make sure that public morality is upheld in all the areas we have discussed. To be able to do this, we need to uphold the omolúwàbi ethos. The unfortunate thing is that this ethos is gradually losing its hold on the average Nigerian. Despite this however, there are still some individuals in Nigeria who can be regarded as omolúwàbí. Many of them have been driven away from politics because there is no public morality and they are not willing to soil their hands in the political game. There is no doubting the fact that the political scene has been messed up. One way to salvage the debilitated political environment is the influx of the omolúwàbi onto the political scene. This has the critical advantage of challenging the amorality of realpolitik in Nigeria. Such an influx must necessarily be hinged on the efficacy of a public enlightenment program that explores the critical relationship between public morality, patriotism and good governance.

There is a sense in which the fight for the soul of the Nigerian state must commence at the level of the family and its connection to the state. The family is one social institution that possesses the capacity to jumpstart the moral rearmament that is critical to democratic rejuvenation in Nigeria. Just as we saw in Aristotle, a virtuous individual is the function of a dedicated educational training that begins in the home, and with even more dedicated socializing agents-the parents and the teachers. In the traditional Yorùbá culture, after a child had been welcomed into the family through a proper naming ceremony, home training would begin. The naming must be proper name in the sense that ilé là ń wò ká tó sọmọ lórúkọ ("one considers the home before 
giving a child a name"). This is one of the reasons why children were always told to be careful not to soil the names of their families.

Yorùbá cultural tradition stresses that the parents are the first teachers of the children, instructing them on the proper way of relating to their parents, elders and grownups, people of the same age group, and other people in the community. Members of the extended family who normally lived together in the same compound were also involved in the upbringing process. The training in the family is a training in morality and it is a collective responsibility of the parents and also the individuals in the society. According to the Yorùbá, eni kan ní bímọ, șùgbọ́n igba ojú nií tọ ọ ("a child is given birth to a single person, but it is the entire community that takes responsibility for training the child"). The essence of this is to ground the child in codes of manners, conventions, customs, morals, superstitions, taboos and laws of the society that make one an omọlúwàbí. In consonance with this, Fadipe remarks that

It is chiefly within the extended family, that is, from members of his compound that a child obtains the bulk of his education as a member of the society. Since the child cannot be continuously under the eyes of his parents and elder brothers and sisters, various member of the extended family take hand in his education at one time or another $(1970,212)$.

The importance of this extended family training is that it afforded the child "frequent opportunities of various experiences not only of the practical effects of many items of the social codes but also of the unpleasant consequences of attending their infraction" (Fadipe 1970, 213). The way offenses are handled in the extended family presented the growing child the opportunity to learn. It was always a thing of shame in the family for the children to misbehave. It was seen as a failure on the part of the parents. Such parents were always reprimanded and advised to put their houses in order (Babatunde 1992). Children are trained from this foundational period because the Yorùbá do not recognize anyone who is found wanting in good character. For the Yorùbá, it is significant to foreground a good name more than the acquisition of material wealth; hence the, proverb: orúkọ rere sàn ju wúrà àti fàdákà lọ ("a good name is better than the possession of silver and gold").

Contemporary society is unlike the traditional Yorùbá context. Due to increasing urbanization and industrialization, extended family members do not live together again as before. This has a significant impact on the child upbringing culture. What we see today are parents sending their children to boarding school before the age of seven. This does not allow the children to have first-hand training and education from their parents. Such children suffer alienation from their parents and the community that ought to constitute 
the socializing agents. It is this inability to learn from the family that accounts for the inability to develop certain social virtues, which eventually turns them into social misfits.

From the forgoing, it can be deduced that the problem with upholding public morality in Nigeria is a foundational problem. It is essentially the failure of the family to rise to its responsibility in the moral upbringing of children. It then becomes imperative that in order to operationalize the omolúwàbi ethos, significant policy attention must necessarily be focused on childhood and primary education.

The second level at which the fight for the soul of Nigeria is fundamental has to do with public education and enlightenment. In this case, the success or failure of this enlightenment campaign would derive from the intersection of the collaboration between the families, the government and its agencies (like the National Orientation Agency [NOA]), non-governmental organizations (NGOs) and the media. Education plays a significant role in the formation of an ethically and morally stable mature human person. It should be noted that childhood education is important in initiating moral development. There are three aspects to the traditional Yorùbá education as identified by Olaiya, namely, ẹkọ̣i ilé (home training), ẹk oọ ișé (vocational training) and ẹkoọilú (civic training) $(2017,676)$. All these are relevant indices for assessing whether an individual is an omolúwàbí. Home training is very important because, as already noted, it is foundational. However, home training alone may not take care of the vocational and civil aspects of the education. This can be taken care of through public education. However, since virtue character is more important, from the point of view of the Yorùbá, there is the need for public education to also complement what is being done at the household level by including in the school curriculum ethics and moral thinking. It is important to note that childhood education does not take place only at the household level. It also takes place at the school level and will serve to reinforce what is learn at the household level. Most children enter primary schools at the age of five to six years. These are still formative years in the life of the children that the society must take into consideration.

Ethics is the foundation for our human relationship to one another and to the world around us. Its purpose is the preservation of human dignity and the conditions for living a good life. The objective of including ethics and values education in the curriculum of education at the childhood level is

to stimulate ethical reflection, awareness, responsibility, and compassion in children, provide children with insight into important ethical principles and values, equip them with intellectual capacities (critical thinking and evaluation, reflection, discovery, understanding, decision-making, 
non-cognitive abilities like compassion) for responsible moral judgment, to develop approaches to build a classroom or school environment as an ethical community, and to reflectively situate individuals into other local and global communities with a mission to contribute to the common good. All this enables pupils to overcome prejudice, discrimination, and other unethical practices and attitudes (Ćurko et al 2010, 6).

The imperative of moral education is consequent upon the fact that education in the strict sense, which does not involve moral education, may produce such qualities as linguistic facility, mathematical acumen and intelligence but these are not virtues since they are not character traits. Though these qualities have great human values that are required for societal development, it is possible for individuals to possess them and still be immoral, and consequently become unfit to be called a person in the society. For as Afolayan rightfully notes,

Human are to strive to become omolúwàbi or a good person. And to achieve this state, attention is not paid to outward configuration of beauty (even though the Yoruba are noted for their unique sense of fashion) but rather an inward development of character... this is the moral import of being called Eniyàn, someone with character of iwa. S when the Yoruba say "O ò ki i șe èniyàn" (you are not a person), that statement is meant to down grade such individual from personhood to the state of an animal. This immediately reveals that personhood is earned within the context of the Yoruba moral universe. It is a positive ontological progression, a moral maturation in time, from a mere individual to a dignified omọlúwàbí (2017, 886).

What can uphold the omọlúwàbí ethos, and consequently public morality, is putting in place and sustaining and educational paradigm that involves moral aims, that is, the promotion of desirable and admirable character traits. What this indicates is the need to include virtue ethics in our educational curriculum. The purpose is to habituate the individual in virtues such as integrity, self-control, patience, respect, kindness, and so on through teaching. That this should begin at childhood is underscored by the assumption that character habituation begins at childhood. Once these virtues are ingrained in the child, virtue becomes a lifelong pursuit for him or her. 


\section{Conclusion}

The basic thrust of this paper is that the Yorùbá omọlúwàbi ethos can be a template for rethinking the glaring lack of public morality in Nigerian politics. Given that Nigeria has had five back-to-back elections since the country entered to the fourth republic in 1999, and the fact that there are democratic structures already in place, we can say that Nigeria has entered into a democratic dispensation. What is left is to ensure a democratic consolidation that will facilitate the empowerment of the social contract between Nigerians and their government. One significant dynamics in this consolidation process is public morality and how its presence or absence affects democratic institution building. This paper has shown that the realities of election rigging, violence, vote selling and buying, embezzlement, and the flagrant abuse of power that define the Nigerian democratic experience demonstrate lack of public morality. This, we argued, can be remedied through a policy attention to morality as a significant core of politics. This is what Aristotle and the Yorùbá omọlúwàbí ethos demonstrate. The Yorùbá and Aristotle have similar conceptions that ground character habituation as being central to public morality. This challenges the Nigerian state to rethink its policies on public education and public enlightenment. Charity, it becomes clear now, begins at home. And home is where a child learns how to deal with others in the public.

\section{Works Cited}

Afolayan, Adeshina (2017). "From the Cosmos to the Society: Worldview as/ and Philosophy", in Toyin Falola and Akintunde Akinyemi (eds.), Culture and Customs of the Yoruba (Austin, Texas: Pan-African University Press), 877-889

Akanbi Grace Oluremilekun and Jekayinfa, Alice Arinlade (2016) "Reviving the African Culture of 'Omoluabi' in the Yoruba Race as a Means of Adding Value to Education in Nigeria”. International Journal of Modern Education Research, Vol. 3 No. 3, 13-19.

Akinola, Anthony (2013). Democracy in Nigeria: Thoughts and Selected Commentaries (North Carolina: Rosendale Books).

Anele, Douglas (2010), "Politics and Morality in Nigeria: A Critical Analysis," Vanguard,

November 14. www.vanguardngr.com/2010/11/ politics-and-morality-in-nigeria-a-critical-analysis-1/.

Apter, Andrew (1992), Black Critics and Kings: The Hermeneutics of Power in Yoruba Society (Chicago: The University of Chicago Press).

Aristotle (2004), Nicomachean Ethics, translated and edited by Roger Crisp (Cambridge: University of Cambridge Press). 
Babatunde, E. D. (1992), Culture, Religion and the Self: A Critical Study of Bini and Yoruba Value Systems in Change (New York: Edwin Mellen Press).

Bernadin, Joseph Cardinal (1998), A Moral Vision for America, edited by John P. Langan (Washington, D.C.: Georgetown University Press).

Bewaji, John A. Isola (2004), "Ethics and Morality in Yoruba Culture", in Kwasi Wiredu (ed), A Companion to African Philosophy (Malden, MA: Blackwell Publishing Ltd), 396-403.

Ciulla, Joanne (2003), The Ethics of Leadership (California: Thomson Wadsworth).

Ćurko, Bruno; Feiner, Franz; Gerjolj, Stanko; Juhant, Janez; Kreb, Kerstin; Mazzoni, Valentina; Mortari, Luigina; Pokorny, Svenja; Schlenk, Evelyn and Strahovnik, Vojko (2015), Ethics and Value Education: Manual for Teachers and Educators. Retrieved from http://www.ethics-education.eu/ resources/Manual Teachers EN.pdf.

Diamond, Larry, Juan J. Linz, and Seymour Martin Lipset (1990), Politics in Developing Countries: Comparing Experiences with Democracy (Boulder: Lynne Rienner Publishers).

Diamond, Larry (1988). Class, Ethnicity and Democracy in Nigeria: The Failure of the First Republic. New York: Syracuse University Press.

Durotoye, Adeolu (2014), "Political Assassination and Nigeria's 4th Republic: 1999-2007," Kuwait Chapter of Arabian Journal of Business and Management Review, Vol. 3, No.11, 235-242.

Fadipe, N. A. (1970), The Sociology of the Yoruba (Ibadan: Ibadan University Press).

Faleti, Adebayo (2009), "Omolúàbí-The golden attribute of a Yorùbá-man: Growing or dying?” in Adedotun Ogundeji and Adeniyi Akangbe (eds.), Omolúàbí: Its Concept and Education in Yorùbá Land (Ibadan: Ibadan Cultural Studies Group), 113-127.

Falola, Toyin, and Adebayo, Akanmu (2000), Culture, Politics and Money among the Yoruba (London: Transaction Publishers).

Franceschet, A. (2009), "Democratic Ethics: An Introduction," in A. Franceschet (ed.), The Ethics of Global Governance (London: Lynne Rienner Publishers), 21-28.

Gbadegesin, Segun (1998), "Individuality, Community and the Moral Order", in Pieter Hendrik Coetzee and Roux, A. P. (eds.), African Philosophy Reader (New York: Routledge). 292-305.

Hauser, Gerard A. (1999) "Aristotle on Epideictic: The Formation of Public Morality", Rhetoric Society Quarterly, Vol. 29, No. 1, 5-23.

Huntington, Samuel (1996) "Democracy for the Long Hall," Journal of Democracy, Vol. 7, No. 2. 3-13. 
Igbafe, Afeaye Anthony and Offiong, O. J. (2007), "Political assassinations in Nigeria: An Exploratory Study," African Journal of Political Science and International Relations, Vol. 1 (1). 9-19.

Jamiu, Hakeem (2007), "Yoruba Politics and the Concept of 'Omoluabi'," Retrieved from http://www.nigerianmuse.com/ spotlight/?=Yorùbá_Politics_And_The_Concept_Of_Omo

luabi_by_Hakeem_Jamiu.htm.

Jansen, Nils (1998), “The Validity of Public Morality,” Archives for Philosophy of Law and Social Philosophy, Vol. 84, No. 1, 1-15.

Mafunisa, M. J. (2003), "Conflict of Interest: Ethical Dilemma in Politics and Administration," South African Journal of Labour Relations, Winter, 4-22.

O'Rourke, P. J. (2010), Don't Vote: It Just Encourages the Bastards (New York: Atlantic Monthly Press).

Olaiya, Toyin, (2017), "Childbirth, Childbearing, and Child Education", in 'Toyin Falola and Akintunde Akinyemi (eds.), Culture and Customs of the Yoruba (Austin, Texas: Pan-African University Press), 669-681.

Olunlade, Funmilola (2017), "Ethics, Social Control, and Management Structure”, in 'Toyin Falola and Akintunde Akinyemi (eds.), Culture and Customs of the Yoruba (Austin, Texas: Pan-African University Press), 805-815.

Tessitore, Aristide (1996), Reading Aristotle's Ethics Virtue, Rhetoric, and Political Philosophy (New York: State University of New York Press).

Steinberger, Peter J. (2000), Readings in Classical Political Thought (Indianapolis: Hackett Publishing Company, Inc.)

Vasudevan, Parvathi (2007), "Elections as a Litmus Test in Nigeria," Economic and Political Weekly, Vol. 42, No. 26, 2498-2501.

Waldo, Dwight (1974-1975), "Reflections on Public Morality," Presidential Studies Quarterly, Vol. 4/5, Vol. 4, no. 3/4 - Vol. 5, No. 1, 43-53.

Weinstein, Michael A. (1973) "The Sociology of Public Morality: Talcott Parsons and Phenomenology", Sociological Focus, Vol. 6, No. 2, 10-31.

Wellborn, Charles (1978) "Public and Private Morality: Where and How do we Draw the Line", Journal of Church and State, Vol. 20, No. 3, 491-505.

Willbern, York (1984) "Types and Levels of Public Morality", Public Administration Review, Vol. 44, No. 2, 102-108.

Wojtasik, Waldemar (2013) "Functions of Elections in Democratic Systems", Political Preferences, No. 4, 25-38. 